\title{
Characterization and variability of the prokaryotic community in sediments from Salar de Lagunilla, Northern Chile
}

\section{Caracterización y variabilidad de la comunidad procariota en sedimentos del Salar de Lagunilla, Norte de Chile}

\author{
Cristy A. Medina Armijo \& Ruben Moraga Mamani \\ Laboratorio de Ecología y Microbiologia Ambiental, Facultad de Recursos Naturales Renovables, Universidad Arturo Prat, Av. \\ Arturo Prat 2120, Iquique, Chile \\ E-mail: rmoraga@unap.cl
}

\begin{abstract}
Fluorescence in situ hybridization (FISH) with rRNA-targeted oligonucleotide probes was used to investigate the abundance of prokariotic community from the sediments of different sites and along a temporary-space scale from Salar de Lagunilla, a high-altitude athalassohaline wetland in the Chilean Altiplano. Six different taxonomic groups were studied: alpha, beta, gamma proteobacterias, sulfate-reducing of the delta subclass of Proteobacteria ${ }_{2}$ Cytophaga-flavobacteria and the domain Archaea. The analyses showed the Archaea domain and Cytophaga-flavobacteria group (33.6 \% - 20.2 \%, respectively) as the dominant group, whereas the groups with minor abundance corresponded to alpha and Beta-proteobacteria (10.7 - $15.5 \%)$. The prokariotic communities in the sediments also developed differently, as shown by Fluorescence in situ hybridization (FISH) and by nonmetric multidimensional scaling analysis. Changes in prokariotic community composition were followed during three years, where there was a difference in the abundance of the domain Archaea, during the dry season (March-August 2006), which demonstrated the existence of temporary differences, but not space. In addition, Canonical correspondence analysis revealed that the prokaryotic community composition could be influenced by some environmental factors, where important components of the ecosystem such as, limestone and carbon, could play a role in the distribution and composition of the prokaryotic community.
\end{abstract}

KEYwords: fluorescence in situ hybridization, salt flats, Andean Altiplano.

\section{RESUMEN}

Se estudio la composición procariota de los sedimentos asociados a la laguna del salar alto andino de Lagunilla, norte de Chile, mediante la técnica de Hibridación in situ Fluorescente (FISH), a lo largo de una escala espacio-temporal. Se estudiaron seis diferentes grupos de la comunidad procariota alfa, beta, gamma protobacterias, sulfatoreductoras, Cytofagas-flavobacterias y el dominio Archaea. Los análisis mostraron que el grupo más dominante fue el Dominio Archaea y Cytofaga-flavobacteria (33.6\% y 20.2\%), mientras que los grupos con menor abundancia corresponden alfa y beta-protobacteria (10.7 y 15.5\%). Se analizaron los cambios en la composición de la comunidad microbiana, a través de un análisis de escalamiento multidimensional no métrica. Los cambios en la composición de la comunidad procariotas fueron seguidos durante tres años, donde se observó una diferencia en la abundancia del dominio Archaea, durante la estación seca (marzo-agosto de 2006), el cual demostró la existencia de diferencias temporales, pero no espaciales. Los análisis de correspondencia Canónica, revelaron que la composición procarionte fue influenciado por algunos factores ambientales, siendo la caliza y el Carbono componentes de importancias en este ecosistemas, los cuales juegan un rol en la distribución y composición de la comunidad procariota.

Palabras Claves: Hibridación in situ Fluorescente, salares, Altiplano Andino.

\section{INTRODUCTION}

Salar de Lagunilla is located in the Chilean altiplano, at $3800 \mathrm{~m}$ of altitude, is considered an athalassohaline system, because the composition of water is different from the seawater (Oren 2002). The waters of the lagoon have a variable salinity and $\mathrm{pH}$ neutral where the principal ionic composition corresponding to $\mathrm{Na}^{+}, \mathrm{K}^{+}$ and $\mathrm{Cl}^{-}$. Abiotic condition in the altiplano including, their geographical isolation and remoteness, high UV radiation and low dissolved oxygen concentration, strong variation in atmospheric pressure and, low temperature in the night 
and high temperature in the daily (Rodríguez-Valera 1988; Ventosa 2006). In addition, the Chilean altiplano is characterized by two very different seasons, a wet period (characterized by the input of storm-water during the months of January and February) and dry period with minimal or low rainwater in the rest of year (Karzulovic \& Garda 1979). All these factors are crucial for biota inhabiting these environments, to be adapted to this extreme condition.

The study of microbial diversity and the distribution of microorganisms that inhabit in salt lakes, are crucial since these types of microorganism play a fundamental role in biogeochemical cycles such as carbon and nutrients. As example, the study of the microbial composition in saline environments might present potentially interesting in biotechnological processes as the bioremediation, UVblockade and new antibiotics production. Also the study of their participation in biogeochemical processes as degradation and remineralization of the organic matter could provide information about he evolution of the Earth (Dundas 1998; Hoehler et al. 2001).

In the present study, we describe the composition and abundance of prokaritic comunity in the sediment samples at, five contrasting sites from Salar de Lagunilla using Fluorescent in Situ Hybridization (FISH) technique has been widely used in studies of microbial ecology (Fazi et al. 2007; Pernthaler \& Amann 2005; Glöckner et al. 2000; Llobet-Brossa et al. 1998; Snair et al. 1997; Amann et al. 1991), providing an important tool to study the composition of microbial communities. In addition, we also studied the changes in temporary space induced by environmental factors, whit sediment samples taken during three years.

\section{MATERIAL AND METHODS}

SITE DESCRIPTION AND SAMPLING

The study was developed in the Salar de Lagunilla, located in the Andes mountains to the coast $155 \mathrm{~km}$ north of Chile $\left(19^{\circ} 56^{\prime} 01^{\prime \prime} \mathrm{S} 68^{\circ} 50^{\prime} 54^{\prime \prime} \mathrm{W}\right)$. There were established five sites of permanent sampling in the lagoon including from north to south, realizing the compilation of the samples between March 2006 and February 2008. (Figure 1)

The samples were extracted from the superficial sediments of the lagoon by core (10- $\mathrm{cm}$ of length and $3 \mathrm{~cm}$ width), saved immediately to hermetic bags and fixed directly in $1 \%$

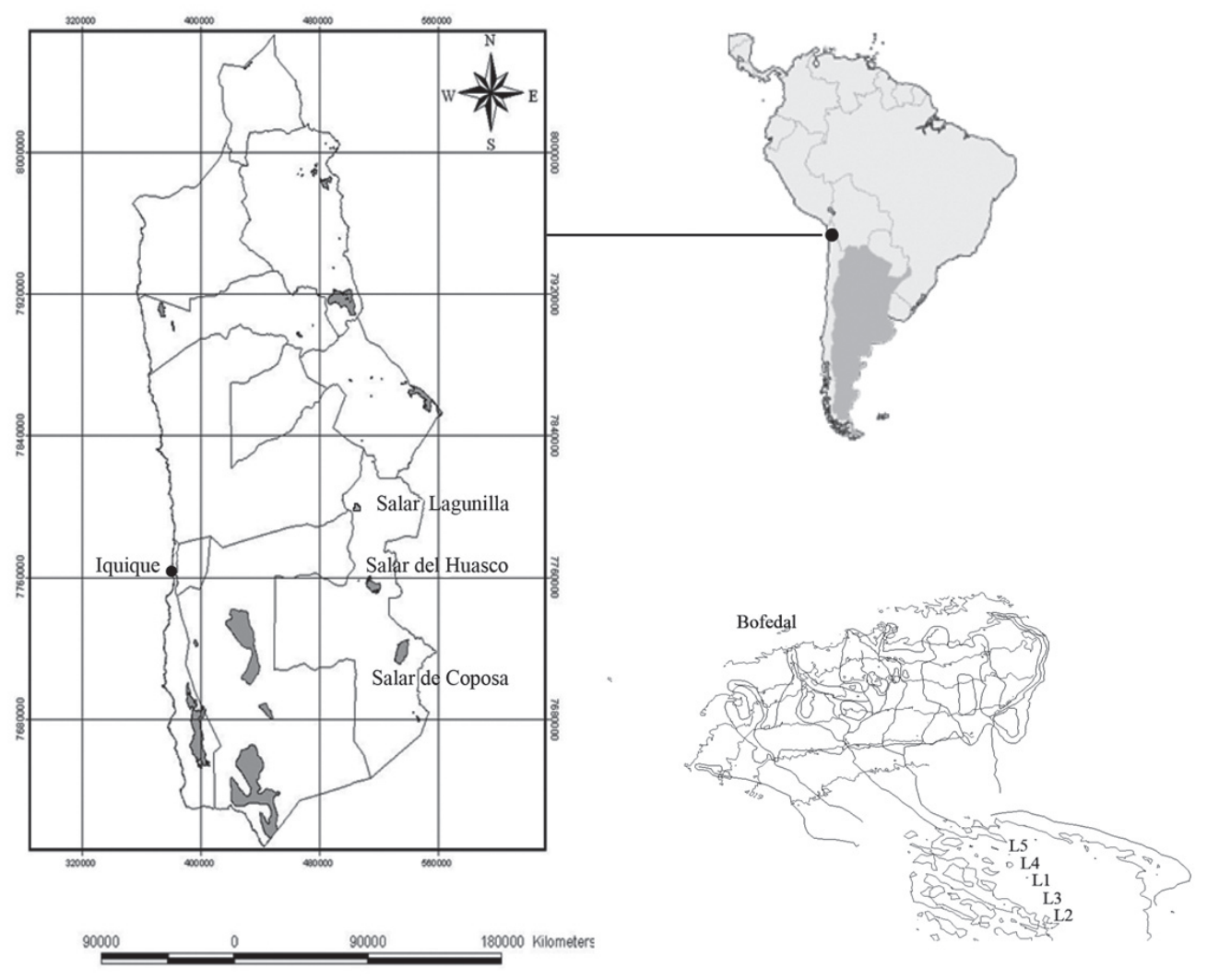

FIGURE 1. Map indicating the location of Salar de Lagunilla and the sampling sites.

Figura 1. El mapa indica la localización del Salar de Lagunilla y puntos de muestreo. 
formalin-phosphate-buffered saline (PBS) (composed of $0,05 \mathrm{M} \mathrm{Na}_{2} \mathrm{HPO}_{4}, 0,85 \% \mathrm{NaCl}$ [ $\mathrm{pH} 7$ in water]). The samples were transported at $4^{\circ} \mathrm{C}$ and processed inmediately upon return to the laboratorythen, withing $5 \mathrm{~h}$ of sampling. From each sample was performed in surface sediment mix which took 0.5 grams, the formalin-fixed samples wer washed in PBS and centrifuged at $10.000 \mathrm{rpm}$ for 5 minutes and then he supernatant is stored under following conditions in ethanolPBS $(1: 1)$ at $20^{\circ} \mathrm{C}$. Sample was diluted and treated by mild sonication for 30 pulses each performed a second and then continues with a series of $5 \mathrm{~min}$ of centrifugation at 4,000 $\mathrm{rpm}$. Washed sample was taken $30 \mu \mathrm{l}$ for be filtered in 0.2 $\mu \mathrm{m}$ pore-size polycarbonate filter, $22 \mathrm{~mm}$ in diameter with $1 \mathrm{ml}$ of sterile distilled water, yielding two filtered samples, which were subsequently analyzed by FISH.

\section{Cy3-LABELED OLIGONUCLEOTIDE PROBES}

Thespecific probes for recognition of the Bacteria domain (ALF1b, BET42a, GAM42a, SBR385, CF319a) and Archaea (ARCH915), were used for the specific detection of the object cells. Probes with in order to optimize the hibridization conditions, non-fluorescent competitors probes were used under the same conditions of BET42a and GAM42a probes (Manz et al. 1992). The specific oligonucleotide sequences of CY3-labeled probes and the hybridization conditions are summarized in the Table 1.

STAINING AND CELL COUNTS OF SAMPLES

To perform FISH, Filters were quartered with a razor blade, ande the section (6 to 7) were placed face up on the glass slide. Aproximately $20 \mu \mathrm{l}$ of preheated hibridization solution was placed on each section filter, and $50 \mathrm{ng}$ specific probes were added in each section of filtere. The hibridization solution contained 20 to $35 \%(\mathrm{p} / \mathrm{v})$ formamide (depending on the experiment; see table 1$)$, and a mixture (5M NaCL, $1 \mathrm{M}$ Tris- $\mathrm{HCl}[\mathrm{pH} 7,2], 10 \%$ sodium dodecyl sulfate [SDS]) and incubated at $46^{\circ} \mathrm{C}$ for 2 hours.

Afterwards, the filters sections were incubated in $10 \mathrm{ml}$ of prewarmed washing buffer at $48{ }^{\circ} \mathrm{C}$ for $15 \mathrm{~min}$. The washing solution consisted of (20 mM Tris- $\mathrm{HCl}(\mathrm{pH} 8), 5 \mathrm{mM}$ EDTA, $0.01 \% \mathrm{SDS}$ and variable concentration of $\mathrm{NaCl}$ ). A formamide concentration of $35 \%$ was used $80 \mathrm{mM}$ and $20 \%$ was used $0,225 \mathrm{mM}$ of $\mathrm{NaCl}$. The filter sections were dried on blotting paper, placed back on a glass slide, and covered whith $50 \mu \mathrm{l}$ of DAPI solution, final concentration, 2 to $5 \mu \mathrm{g} / \mathrm{ml}$, for $5 \mathrm{~min}$ at room temperature in the dark. Then, the filters were gently washed in $2 \mathrm{ml}$ of $0,2 \mu \mathrm{m}$-filtered destiled water and ethanol, dried on blotting paper, and mounted on glass slides.

The filter sections were inspected whith a fluorescence microscope, equipped whith a $50-\mathrm{W}$ high-pressure mercury bulb and specific filter sets (DAPI [Zeiss 01]), Cy3 (Chroma HQ 41007). Each microscopic field was first viewed with CY3 filter, before switching to the DAPI filter, to avoid bleaching of CY3 during the DAPI count. For each samples and probe, more tan 500 cells were counts; for the DAPI examination, more then 1500 cells were counted per samples. All probespecific cell counts were presented as the percentage of cell counts by DAPI. The mean abundances and standard deviations were calculated from the counts of 10 to 20 randomly chosen fields on each filter section. The account of the abundance of prokaryotic cells per gram was performed using the protocol and algorithms proposed by (Fry 1986).

TABLE 1. Oligonucleotide Sequences and Percentage of formamide (\% FA).

TABLA1. Secuencia de Oligonucleotidos y porcentajes de formamida.

\begin{tabular}{|c|c|c|c|c|c|}
\hline Probe & Secuencia $\left(5^{\prime}-3\right)$ & Posición en ARNr ${ }^{\text {a }}$ & Specificity & $\%$ FA in situ ${ }^{\mathrm{b}}$ & Reference \\
\hline ALF $1 b$ & GGTAAGGTTCTGCGCGTT & $16 \mathrm{~S}(968-986)$ & $\alpha$-proteobacteria, & $20 \%$ & Manz et al. 1992 \\
\hline BET $42^{\mathrm{a}}$ & GCCTTCCCACTTCGTTT & $23 \mathrm{~S}(1027-1043)$ & $\beta$-proteobacteria & $35 \%$ & Manz et al. 1992 \\
\hline $\operatorname{Gam} 42^{\mathrm{a}}$ & GCCTTCCCACATCGTTT & $23 \mathrm{~S}(1027-1043)$ & $\gamma$-proteobacteria & $35 \%$ & Manz et al. 1992 \\
\hline CF319a & TGGTCCGTGTCTCAGTAC & $16 \mathrm{~S}(319-336)$ & $\begin{array}{c}\text { Cytofaga- } \\
\text { flavobacteria }\end{array}$ & $35 \%$ & Manz et al. 1996 \\
\hline SBR 385 & CGGCGTCGCTGCGTCAGG & $16 s(385-402)$ & $\delta$. -protobacteria & $35 \%$ & $\begin{array}{c}\text { Amann et al. (1990a, } \\
\text { 1995b) }\end{array}$ \\
\hline ARCH915 & GTGCTCCCGCAATTCCT & $16 \mathrm{~S}(915-934)$ & Archaea & $35 \%$ & Stahl \& Amann, 1991 \\
\hline
\end{tabular}

a Escherichia coli, numbering (Brosius . 1981).

b Percent formamide (FA) in situ hybridization buffer. 
STATISTICAL ANALYSIS

Of the data matrix was constructed Bray-Curtis similarity. A non-metric multidimensional scaling analysis (NMDS) was performed to study the changes in the distribution patterns and variability of the prokaryotic community. Them similarity analysis comparing the sampling sites were performed by ANOSIM (Analysis of Similarity). In this sense, ANOSIM shows an R-value statistic, which determinate the distance ranges within and between groups or samples. In general this value can be divided into 3 categories; $\mathrm{R}>0,75$ : indicates that there are large differences and treatments or groups are well separated, $\mathrm{R}>0.5$ : indicates (groups/samples) as separated, but overlapping, and $\mathrm{R}<0,25$ : indicates little or no differences, and treatments or groups are barely separable (Clarke 1993). To avoid differences in the distribution of data by the sample size, proportions were transformed to $\log (\mathrm{x}+1)$ (Ramette 2007). All tests were carried out using PRIMER software version 6 (Clarke \& Gorley, 2005).

To study if the composition of biological community was influenced by environmental parameters, a canonical correspondence analysis (CCA) was performed using the Community Ecological Analysis software (Ecom II version 2.01)-(Seaby \& Henderson, 2007), was used to compared the prokaryotic abundance (FISH) matrices with the enviromental variables (physicochemical matrices). Boyh FISH data and enviromental variables were $\log (\mathrm{x}+1)$ transformed. Forward selection was used to rank the environmental variables in importance for determining the species data (Multicollinearity test). The environmental (explanatory) variables used were nitrogen concentration measured as $\mathrm{NO}_{3}$, percentage of limestone measured as $\left(\mathrm{CaCO}_{3}\right)$, percentage of easily oxidized carbon $(\mathrm{CO})$ and electrical conductivity $(\mathrm{EC}[\mathrm{mS} / \mathrm{cm}])$.

\section{RESULTS}

ESTIMATING THE ABUNDANCE OF PROKARYOTES

Table 2 shows the variation of cell counts per gram (cell g-1) and percentages of FISH counts during the months of the study. The maximum value of DAPI counts $\left(6.98 * 10^{7}\right.$ cells $\left.\mathrm{g}^{-1}\right)$ was detected during August 2006 and the minimum $(2.39 * 10$ ${ }^{7}$ cells g-1 ${ }^{-1}$ was detected in April 2007; being the average DAPI counta total of $3.26^{*} 10^{7}$ cells $\mathrm{g}^{-1}$. In addtion, the percentage of FISH detectable cells to the Bacteria and Archaea domains was $9.05 \mathrm{E}+05$ and $1.08 \mathrm{e}+06$ (cells $/ \mathrm{g}$ ) respectively.

These sediments have a hight diversity of cell morphologies as, filamentous bacillary forms, bow-shaped rod, coccoid, flagellum cell, bacilli in chains, and among them were large consortia bacteria. Most of the cell identifica in the sediment showed a homogeneous morphology of thin short road. (Figure 2).

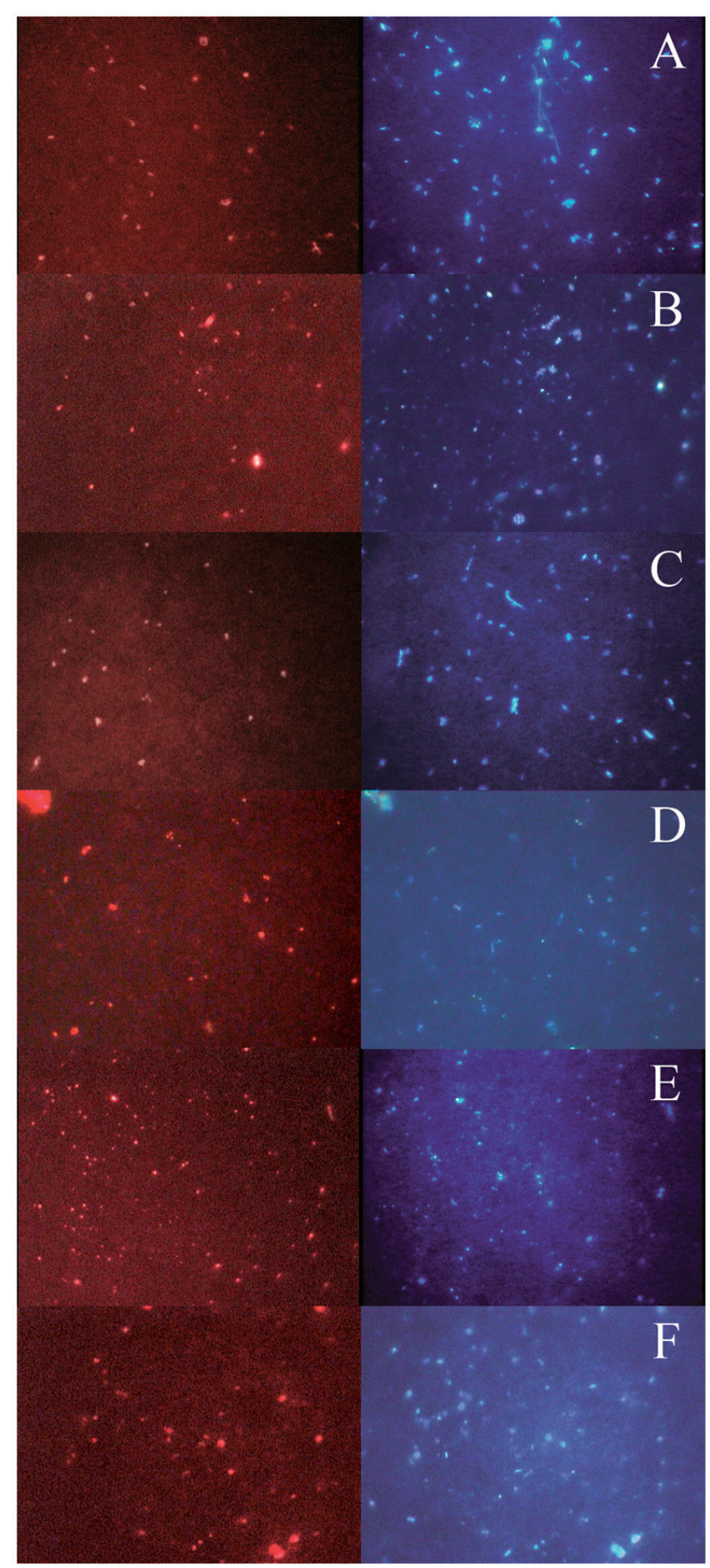

FIGURE 2. Abundance procariota of the sediments associated with Salar de Lagunilla in cell/ grams. (A) Alfa-proteobacteria (B) Beta-proteobacteria (C) Gamma-proteobacteria (D) Cytofagaflavobacteria (E) Bacteria Sulfatoreductoras (F) Archaea.

Figura 2. Abundancia procariota de los sedimentos asociados al Salar de Lagunilla en Células/gramos. (A) Alfa-proteobacterias (B) Beta-proteobacterias (C) Gamma-proteobacterias (D) CytofagaFlavobacterias (E) Bacterias Sulfatoreductoras (F) Archaea. 
The groups with major variability were the domain Archaea and Alpha-proteobacteria with relative percentages of hybridized cells (FISH) were from $11.8 \pm 5.2$ to $34.7 \pm 10.7$ $\%$ and from $7.9 \pm 2.0$ to $31 \pm 8.8 \%$ respectively, whereas that the unalterable groups were Gamma-proteobacteria and Cytofaga-flavobacteria with relative percentages of hybridized cells from $15.7 \pm 4$ to $22.5 \pm 8.5 \%$ and from $14.6 \pm 10$ to $28.7 \pm 2.3 \%$ respectively. On the other hand, the most abundant group corresponded to the Archaea domain with relative abundances of $34.7 \%$ in April, and 29\% during the months of March and August (2006), and from November to February (2007). In the same way, the less abundant detected group was Beta-proteobacteria, showing a relative abundance of 5.5\% during March 2006. Members of sulfate-reducing bacteria group from the subclass Deltaproteobacteria, showed an increase in their relatives abundances during the months of November, 2007 and February, 2008 (25.0 \pm 2.5 and $27.5 \pm 1.2 \%$, respectively), whereas the minor relatives abundances were observed during the months of November, January and April, 2007.

In general the sediments system of the lagoon showed a trend where the domain Archaea and the group Cytofagaflavobacteria were dominant. The members of the sulfate-reducing and Gamma-proteobacterias presented similar abundances. Alpha-proteobacterias and Beta- proteobacteria group were the group with less abundances in the superficial sediments system of the salar de Lagunilla.

PhysicochemicAl RELATIONShIP OF THE PROKARYOTIC COMMUNITY.

To describe the relations between the abundances of the prokaryotic community and the physicochemical variables (Table 3), there was made a canonical correspondence analysis (CCA). The results for the humid period (March, 2006, January, 2007 and February, 2008), makes clear 48.7 $\%$ of the accumulative variance, on the other hand the dry period (August, 2006, November, 2006, April, 2007, August, 2007 and November, 2007), the variable significant for the first two axes explain $45.2 \%$ of the accumulative variance.

The table 4 shows the environmental variables, which contribute, significantly in the Dry period, from bigger to minor contribution in model they are, $\mathrm{NO}_{3} \mathrm{mg} / \mathrm{K}$, Limy $\left(\mathrm{CaCO}_{3} \mathrm{~g}\right), \% \mathrm{p} / \mathrm{p} \mathrm{CO}$ (carbon easily oxidabl) and $\mathrm{CE} \mathrm{mS} /$ $\mathrm{cm}$. For the humid period the significant concentrations were: \% p/p CO, $\mathrm{NO}_{3} \mathrm{mg} / \mathrm{k}$, limestone $\left(\mathrm{CaCO}_{3} \mathrm{~g}\right), \mathrm{CE} \mathrm{mS} /$ $\mathrm{cm}$ and $\mathrm{PO}_{4}^{+3} \mathrm{mg} / \mathrm{k}$ expressed in the axis 1 .

Biplot diagram ordination of CCA analysis shows the patterns of changes in prokaryotic community, which can be explained by environmental variables.

TABLE 2. Total DAPI count and specific FISH studies for months.

TABLA 2. Recuento total DAPI y FISH por meses de estudios.

\begin{tabular}{cccccccc}
\hline \multirow{2}{*}{$\begin{array}{c}\text { Month of } \\
\text { Study }\end{array}$} & Total cell counts & \multicolumn{5}{c}{ Fraction (\%) of total cell (mean \pm SD) detected with probea: } \\
\cline { 3 - 7 } & $\begin{array}{c}\text { (cel/g) } \\
\text { (Mean) }\end{array}$ & ALF968 & BET42a & GAM42a & CF319a & Sbr385 & Arch915 \\
\hline mar-06 & $2.90 \mathrm{E}+07$ & $7.9 \pm 2.0$ & $5.5 \pm 0.5$ & $17.0 \pm 3.9$ & NA $_{\mathrm{b}}$ & $17.4 \pm 0.9$ & $34.4 \pm 3.8$ \\
aug-06 & $6.08 \mathrm{E}+07$ & $11.1 \pm 1.1$ & $17.0 \pm 0.7$ & $18.5 \pm 3.7$ & $\mathrm{NA}_{\mathrm{b}}$ & $18.5 \pm 1$ & $33.5 \pm 2.8$ \\
nov-06 & $2.95 \mathrm{E}+07$ & $19.0 \pm 6.9$ & $16.9 \pm 4.5$ & $20.4 \pm 10.9$ & $14.6 \pm 10$ & $13.1 \pm 12.6$ & $13.6 \pm 7.2$ \\
jan-07 & $2.39 \mathrm{E}+07$ & $14.6 \pm 5.7$ & $21.2 \pm 8.3$ & $15.7 \pm 4$ & $21.3 \pm 8.1$ & $13.7 \pm 4.8$ & $19.2 \pm 3.2$ \\
apr-07 & $2,42 \mathrm{E}+07$ & $12.3 \pm 4$ & $25.1 \pm 5.1$ & $21.0 \pm 8.1$ & $20.8 \pm 3.7$ & $14.8 \pm 4.1$ & $34.7 \pm 10.7$ \\
aug-07 & $2.84 \mathrm{E}+07$ & $12.6 \pm 5.6$ & $14.8 \pm 3$ & $18.8 \pm 6.8$ & $18.8 \pm 3.4$ & $19.5 \pm 7.8$ & $11.8 \pm 5.2$ \\
nov-07 & $2.76 \mathrm{E}+07$ & $31.0 \pm 8.8$ & $26.7 \pm 5.9$ & $22.5 \pm 8.5$ & $23.0 \pm 5.1$ & $25.0 \pm 2.5$ & $29.6 \pm 1$ \\
feb-08 & $2.73 \mathrm{E}+07$ & $19.0 \pm 4.5$ & $20.6 \pm 4$ & $17.6 \pm 3.4$ & $28.7 \pm 2.3$ & $27.5 \pm 1.2$ & $28.7 \pm 1$ \\
\hline
\end{tabular}

a Detection rate compared with DAPI. Mean and standard deviation were calculated by counting 20 fields in the section of the filter. b Unparsed 
Gayana 80(2), 2016

TABLa 3. Propiedades Físico-Químicas del Salar de Lagunilla.

TABle 3. Physical-Chemical Properties of the Salar de Lagunilla.

\begin{tabular}{cccccccc}
\hline Month of Study & $\mathrm{pH}$ & $\mathrm{CE}(\mathrm{mS} / \mathrm{cm})$ & $\% \mathrm{CO}$ & \% Sulfato & \% Caliza $\left(\mathrm{CaCO}_{3}\right)$ & $\mathrm{NO}_{3}(\mathrm{mg} / \mathrm{K})$ & $\mathrm{PO}_{4}^{+3}(\mathrm{mg} / \mathrm{K})$ \\
\hline March-2006 & 8.1 & 9.0 & 2.1 & 1.5 & 16.4 & $\mathrm{ND}^{\mathrm{a}}$ & $\mathrm{ND}^{\mathrm{a}}$ \\
August-2006 & 7.5 & 6.3 & 1.6 & 1.1 & 13.7 & $\mathrm{ND}^{\mathrm{a}}$ & $\mathrm{ND}^{\mathrm{a}}$ \\
November-2006 & 7.5 & 8.0 & 2.1 & 0.9 & 14.0 & $\mathrm{ND}^{\mathrm{a}}$ & $\mathrm{ND}^{\mathrm{a}}$ \\
January -2007 & 7.5 & 8.5 & 1.7 & 0.9 & 13.8 & 24.4 & 7.1 \\
April -2007 & 7.9 & 4.8 & 1.8 & 0.9 & 13.0 & 28.7 & 9.3 \\
August-2006 & 8.3 & 4.1 & 1.4 & 0.8 & 15.0 & 25.5 & 7.9 \\
November-2006 & 7.1 & 1.7 & 1.4 & 0.6 & 15.1 & 22.7 & 9.6 \\
February -2008 & 7.8 & 8.5 & 1.4 & 0.8 & $\mathrm{ND}$ & 18.9 & 11.2 \\
\hline $\mathrm{ND}^{\mathrm{a}}$, a undetermined & & & & & & &
\end{tabular}

TABLE 4. Intranet values of environmental variables

TABLA 4. Valores intranet de las variables ambientales

\begin{tabular}{cccc}
\hline & Environmental variables & 1 & 2 \\
\hline dry period & $\mathrm{CE}(\mathrm{mS} / \mathrm{cm})$ & 0.04 & 0.91 \\
$\% \mathrm{p} / \mathrm{p} \mathrm{CO}$ & 0.56 & 0.20 \\
$\mathrm{CaCO}_{3}(\mathrm{~g})$ & 0.81 & 0.15 \\
$\mathrm{NO}_{3}(\mathrm{mg} / \mathrm{k})$ & 0.90 & 0.09 \\
& & & \\
Wet Period & $\mathrm{CE}(\mathrm{mS} / \mathrm{cm})$ & 0.14 & 0.40 \\
& $\% \mathrm{p} / \mathrm{p} \mathrm{CO}$ & 0.57 & 0.12 \\
& $\mathrm{CaCO}_{3}(\mathrm{~g})$ & 0.24 & 0.72 \\
& $\mathrm{NO}_{3}(\mathrm{mg} / \mathrm{k})$ & 0.48 & 0.45 \\
$\mathrm{PO}_{4}{ }^{3}(\mathrm{mg} / \mathrm{k})$ & 0.09 & 0.05 \\
\hline
\end{tabular}

The environmental variables are represented by the vectors, which it is constructed by the points of the variables on the maximum inertia projected in the space. The arrows represent the vector direction. The vector length indicates the importance of the variable in the model, and the position of these indicates that so correlated the environmental variable is with the axes. Also the angles between the vectors indicate the correlation that exists between them (a small angle indicates high correlation). The samples are represented by the pictures and indicate the relation with the environmental variables (vector) and his arrangement with environmental variables in the model.

The figure 3 shows the analysis corresponding to the dry period, for this period the available $\mathrm{NO}_{3}$ and the Limestone $\left(\mathrm{CaCO}_{3}\right)$ they are the most important variables for the model, since 1 is narrowly tied to the axis. 
The group Cytofaga-flavobacteria shows a good correlation of negative trend with the limy variable $\left(\mathrm{CaCO}_{3}\right)$ and Gamma-protobacteria correlates negatively with the electrical conductivity (CE), explained in the axis 2 , this one can represent important quantities of you work out soluble.

For the humid period (Figure 3), the most influential variables in the model are the organic carbon easily to oxidize (CO) and the available $\mathrm{NO}_{3}$. The members of the Sulfato-reductors it is correlated by the $\mathrm{NO}_{3}$ positively, Betaproteobacterias is correlated negatively with $\mathrm{CaCO}_{3}$, which explains to itself in the axis 2, Gamma-protobacteria with organic carbon easily oxidable (CO), Alpha-proteobacteria and the Domain Archaea show correlations positive with electrical conductivity, which explains to itself in the axis 2 and Cytofaga-flavobacteria is not correlated by any variable, in general the model shows a correlation with the samples and the variable electrical conductivity (CE).

\section{SPATIO-TEMPORAL VARIABILITY}

In term of the relative abundances of the prokaryotic community, these exhibited a great variability during the study period. In the figure 1 NMDS, shown that March and August, 2006 are different from the rest of the study, these are characterized by presenting high abundances of microorganism of Archaea domain (34.4\% and 33.5\% respectively), whereas the sum of the relative abundances between the groups of the domain Bacteria represent 47.8 $\%$ and $65,1 \%$ respectively, with regard to the rest of the groups analyzed in comparison to other studies periods. On the other hand the figure 4 shows the analysis spreads of NMDS, in this analysis one does not show significant differences between the stations of sampling. For this study there were identified 5 sites of study (L1-L2-L3-L4-L5).

The abundance of the prokaryotic community was compared to be able to observe differences intra and interannual. The ANOSIM showed significant differences with overlapping during the period of study $(\mathrm{R}=0.527, \mathrm{p}<0.001$ ), also an ANOSIM was realized to observe the spatial differences, where significant differences were not observed $(R=0.102$, $\mathrm{p}<0.005$ ).
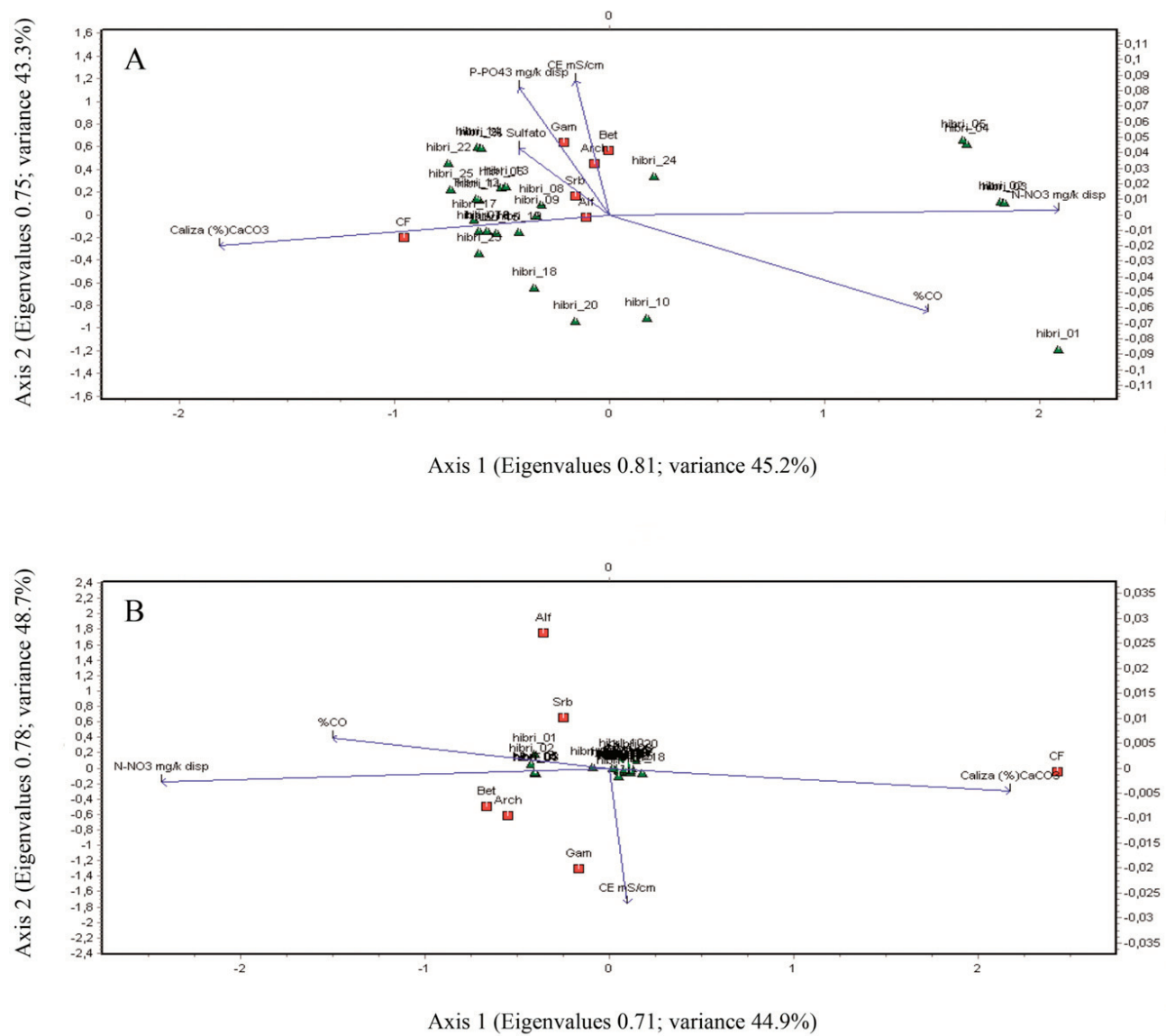

FIGURE 3. Canonical correspondence analysis of the prokaryotic abundance and the environmental variables. (A) Humid period and (B) Dry period.

Figura 3. Análisis de correspondencia canónica de la abundancia procariotas y las variables ambientales. (A) Período Húmedo y (B) período seco. 


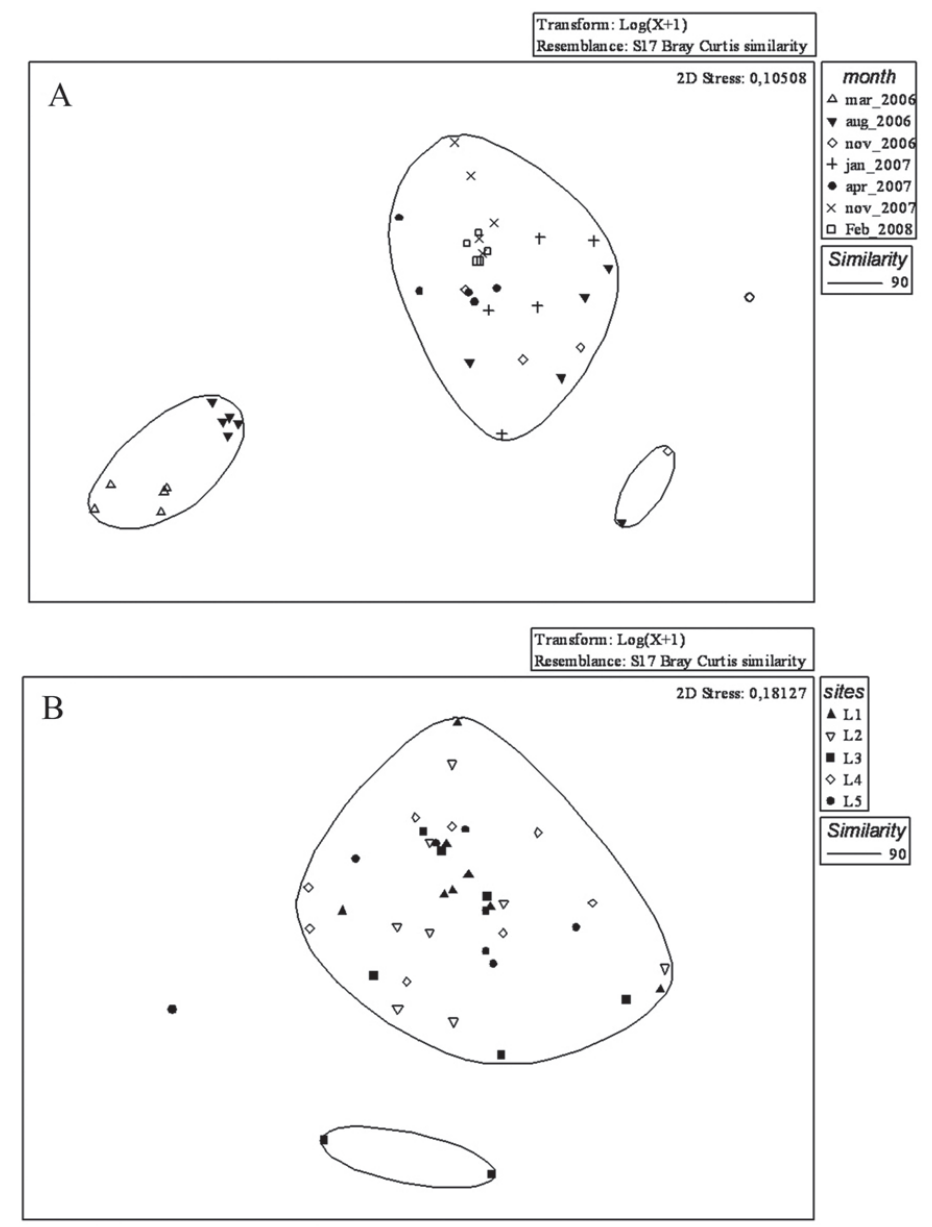

FIgURE 4. (A) NMDS, temporary scale representation of the comunity prokaryotic abundances. Log transformation $(\mathrm{X}+1)$, $\mathrm{Stress}=0.11$ and Randon 999 permutations. (B) NMDS, spatial scale representation of the comunity prokaryotic abundances. Log transformation $(\mathrm{X}+1)$, Stress $=0.18$ and Randon 999 permutations.

FigURA 4. (A) NMDS Representación a escala temporal de las abundancias procariotas comunidad. Transformación Log $(\mathrm{X}+1)$, Estrés $=$ 0.11 y Randon 999 permutaciones. (B) NMDS, representación espacial escala de las abundancias procariotas comunidad. Transformación $\log (\mathrm{X}+1)$, Estrés $=0,18$ y Randon 999 permutaciones.

\section{DISCUSSION}

The Highland Lakes as the Salar de lagunilla represent unique and extreme habitats clearly dominated by various forms of microbial life. However, microbiological studies have been performed only occasionally (Demergaso et al. 2004; Demergaso et al. 2008; Dorador et al. 2008a, 2008b, 2009, 2010). Salar de Lagunilla is considered as a moderately athalassohaline wetland (Table 3), comparable in its phylo-genetic groups with other high-altitude cold aquatic systems (Tibetan Lakes: Dong et al. 2006; Jiang et al. 2006. Atacama Lakes: Demergasso et al. 2004)

In this work, using FISH technique was possible to establish a first approximation of the microbial composition and the most abundant specific groups in the sediments of the Salar de Lagunilla. However, the use of this technique has its limitations, such as the weak signal and lack of specificity of the oligonucleotides. These limitations have been described and solutions have been proposed by Penthaler \& Amann, (2005), thus been possible to be more objective with our results. Moreover it is important to note that the contribution achieved through these studies will help to generate other future investigations.

Bacterial assemblages were dominated by CytofagaFlavobacteria-Bacteriodes (CFB), $28.7 \%$ abundances of hybridized cells). This percentage is high when considering the percentage of coverage with the probe, which is about $38 \%$ (Amann et al. 2008). This group is characteristic in the oceans where it is abundant between the groups (Kirchman 2002), just as this group has been reported in sediments and in environments with high concentrations of salinity (Antón et al. 1999). These results are consistent with others studies, 
where has been observed in athalossahalino lake of the Atacama by PCR-denaturing gradient gel electrophoresis (DGGE) and sequencing of 16S rRNA gene fragments where the tendency for increasing contribution of (CFB) for higher salinities and altituded (Demergasso et al. 2004). In addition, in the sediment samples from three evaporitic basins located in the highlands of northern Chile, has observed the high diversity of bacteroides through of $16 \mathrm{~S}$ rRNA gene clone libraries created with targeted Bacteroidetes-specific primers and separation of specifically amplified gene fragments by denaturing gradient gel electrophoresis (DGGE) (Dorador et al. 2008a). Similar results have also been found in high-altitude lakes from the Tibetan Plateau (Wu et al. 2006).

Cytofaga-flavobacteria have been described for their role in the degrader of complex molecules and high molecular weight cellulose and, has also been seen in the presence of abundant phytoplankton booms and association with some algae that may result in enhanced algal growth (Grossant 1999).

The increase of abundant CF in the wet period, where organic matter and salinity increases, due to the death of organisms from other trophic levels and increased salinity, and your afinity for $\mathrm{CaCO}_{3}$ apparently show that their role is similar to their role in the ocean. Therefore, this group could be the responsible for the degradation of high molecular weight compounds in altiplanic lakes.

The Proteobacteria group is characteristic as a cosmopolitan and grouped according to their habitat, creating divisions in the sea, fresh water or soil (Glockner et al. 2000; Bowman et al. 2003 \& Crump et al. 2004). Alpha and Beta-proteobacteria are the group with the lowest rates of hybridization; this is consistent with studies in the ocean (Glöckner et al. 1999; Cottrell et al. 2000;). These groups are not abundant in saline environments, but it includes mostly the halotolerant bacteria. However this group has been associated with salt deposits, but participating in processes of nitrification (Nold \& Zwart 1998).

Gammaproteobacteria group showed variability in relative abundance in the order of $19 \%$, which has been observed in the work of (Cottrell et al. 2000). This group is characteristic as oxides in aerobic and anaerobic environments (Ollivier et al. 1994), and it has also been shown that members of this group are facultative able to adapt to different environmental conditions. In studies recently, has been observed the present of anoxygenic phototrophic bacteria in the Atacama salar, across application of the functional pufLM genes, was determined a new phylogenetic lineage of phototrophic Gammaproteobacteria (Thiel et al. 2011). Possibly, this group have a role important as primary producers in the salar of Lagunilla
Members of the sulfate-reducing bacteria, showed variability in the abundance in the order of a $13-27 \%$ hybridization of cells in the period of study. This group is important for the degradation of organic matter in sediments, using sulfate as electron acceptor (Ollivier et al. 1994). In the salar de Huasco, has been observed the present of deltaproteobacteria, with a study of $16 \mathrm{~S}$ rRNA gene sequences related to sulfate-reducing bacteria of the genera Desulfobacterium (Dorador et al.2009), this group can have a significant fraction of carbon mineralization in sediments hypersaline.

The salar de Lagunilla is considered as an athalassohaline enviroments, also this system is highly variable depending on the groundwater inputs in different zones of the lake basin and stormwater inputs, especially in the months of January and February, and bacteria have to adapt locally to the new conditions. In this studie the abundance of archaeas comunities exhibit hight contribution in this system above bacterium. Howeber has been described that dominance of Archaea over Bacteria in enviroments where $\mathrm{NaCl}$ concentration close to saturation, here the halobacterias are the dominant (Oren 2002). However, has been observed the predominance of methanogemic archaea and ammoniaoxidizing Archaea in studies in Salar de Huasco (Dorador et al., 2010). Probably, the Salar de Lagunilla presents dominance by methanogemic archaea, because physicalchemical characteristics of the Lagunilla's sediments. This sediment has high carbonates saturation and anoxic sediments forming minerals, being a favorable condition for the adaptability of these organisms.

The environmental variables affected the diversity and composition of bacterial communities strongly. CCAanalysis indicated that the salinity gradients, $\mathrm{CaCO}_{3}$ and carbon organic are the environmental variables more significantly close $50 \%$ of the variance, in specie composition bacterial. The enrichment of carbon and $\mathrm{CaCO}_{3}$, and the salinity gradient clearly increased the abundance of community bacterial in the sediment; however, the concentration of nitrogen (measured as nitrate) and phosphorus (measured as fosfate) do not significantly affect the abundance and bacterial diversity.

The temporal variability in bacterioplankton communities was significantly highly was highly correlated with salinity, $\% \mathrm{CO}$ (organic carbon) and $\mathrm{CaCO}_{3}$; In contrast, spatial variability was relatively small in communities across environments altiplanicos, confirming the observations of microbial diversity and abundance based on FISH. Few studies address temporal and spatial variability using different habitats, Kirchman et al. (2010) identified a pattern where differences into winter and summer in the Arctic Ocean of the bacterioplankton communities was 
minimal compared with spatial variability across their sampling range. Similarly, Fortunato et al. 2012, compares the bacterioplankton community composition from river to surface ocean, by depth from surface to deep ocean, and through time seasonally over an year, by the use of $16 \mathrm{~S}$ ARN, where they observed changes in the spatial variability and correlations with salinity and Depth.

Our study, show temporary changes that may be associated with increased salinity in dry periods and increased rainfall (wet period), which brings an eutrophication. Although, it seems that the salinity gradient is the best indicator of biogeographic distribution in these environments. We also identified significant overlap in communities of Archaea Domain in the dry period.

This study reveals the first analyses of the composition of a prokariotic community, temporary differences are demonstrated and as the environmental factors they are incidental in the structure, distribution and microbial variability of the populations in the Salar de Lagunilla. These results can serve for future investigations, so that the community analyses could be combined by the evolution of the substrates of the sediments.

\section{BIBLIOGRAPHY}

Amann, R., Springer, N., Ludwig, W., Gertz, H. \& Schleifer, K. 1991. Identification in situ and phylogeny of uncultured bacteria endosymbiots. Nature 351:161-164.

Amann, R., Ludwing, W. \& Schleifer, K. 1995. Phylogenetic identification and in situ. Detection of individual Microbial Cell without Cultivation. Microbial Reviews 59:143-169.

Anton , J., Llobet-Brossa, E., Rodríguez-Varela, F.\& Amann, R. 1999. Fluorescence in situ hybridization analysis of the prokaryotic community inhabiting crystallizer ponds. Environmental Microbiology 1:517-523.

BAK, F., \& Pfennig, N.F. 1991. Sulfate-reducing bacteria in littoral sediment of Lake Constance. FEMS Microbiology Letters $85: 43-52$

BraAk Ter, C. 1986. Canonical correspondence analysis: Anew eigenvector technique for multivariate direct gradient analysis. Ecology 67:1167-1179.

Bowman, J.P., Mccammon, S.A., Rea, S.M. \& Mcmeekin, T.A. 2000. The microbial composition of three limnologically disparate hypersaline Antarctic lakes. FEMS Microbiology Letters 183:81-88.

Brosius, J., Dull, T.J., Sleeter, D.D. \& Noller, H.T. 1981. Gene organization and primary structure of a ribosomal RNA operon from Escherichia coli. Journal of Molecular Biology 148:107-127.

Clarke, K.R. 1993 Non-parametric multivariate analyses of changes in community structure. Australian Journal of Ecology 18:117-143.

Clarke, K.R.; Gorley R.N. 2006 PRIMER v6: User manual/ tutorial, PRIMER-E, Plymouth UK.
Cottrell, M.T. \& Kirchman, D.L. 2000. Community composition of marine bacterioplankton determined by $16 \mathrm{~S}$ rRNA gene clone libraries and fluorescens in situ hybridization. Applied and Environmental Microbiology 66:5116-5122.

Crump, B.C., Hopkinson, C.S., Sogin M.L. \& Hobbie J.E. 2004. Microbial biogeography along anestuarine salinity gradient: combined influences of bacterial growth and residence time. Applied and Environmental Microbiology 70:1494-1505.

Demergasso, C. Casamayor, E.O., Chong, G., Galleguillos, P., Escudero, L., Pedros-Alio, C. 2004. Distribution of prokaryotic genetic diversity in athalassohaline lakes of the Atacama Desert, northern Chile. FEMS Microbiology Ecology 48:57-69.

Demergasso, C., Escudero, L., Casamayor, E.O., Chong, G., Balaguí V. \& Pedros-alio, C. 2008. Novelty and spatio-temporal heterogeneity in the bacteria diversity of hypersaline lake tebenquiche (Salar de Atacama). Extremophiles 12:491-504.

Dong, H., G. Zhang, H. Jiang, B. Yu, L. R. Chapman, C. R. Lucas, \& Fields, M. W. 2006. Microbial diversity in sediments of saline Qinghai Lake, China: Linking geochemical controls to microbial ecology. Microbial Ecology 51:65-82.

Dorador, C., Busekow, A ., Vila, I., Imhoff, J. \& Witzel, K.P. 2008A. Molecular analysis of enrichment cultures of amonia oxidizers from the Salar de Huasco, a high altitude saline wetland in northern Chile. Extremophiles 12:405-414.

Dorador, C., Vila, I., Imhoff, J. \& Witzel, K.P. 2008в. Cyanobacterial diversity in Salar de Huasco, a high altitude saline wetland in northern Chile: an example of geographical dispersion?. FEMS Microbiology Ecology 64:419-432.

Dorador, C., Meneses, D., Urrutia, V., Demergasso, C., Vila, I., Witzel, K.P. \& Imhoff I. 2009. Diversity of Bacteroidete in high-altitude saline evaporitic basins in northern Chile. Journal of Geophysical Research 114: G00D05. DOI:10.1029/2008JG000837.

Dorador, C., Vila, I., Remonsellez, F., Imhoff, I. \& Witzel, K.P. 2010. Unique cluster of Archaea in Salar de Huasco, an athalassohaline evaporitic basin of the Chilean Altiplano. FEMS Microbiology Ecology 73:291-302.

Dundas, I. 1998. Was the environment for primordial life hypersaline? Extremophiles 2:375-377.

Fazi, S., Amalfitano, S., Pizzetti, I. \& Pernthale, J. 2007. Efficiency of fluorescence in situ hybrization for bacterial cell identification in temporary river sediments with contrasting wáter content. Sysrematic and Applied Microbiology 30:463-470.

FRY, J. 1988. Determination of biomass. In: Methods in aquatic bacteriology (Ed. Austin, B.), pp. 27-72. Jhon Wiley and Sons.

Fortunato C., Herfor L., Zuber P., Baptista A., Crump B. 2012. Spatial variability overwhelms seasonal patterns in bacterioplankton communities across a river to ocean gradien. ISME Journal 6:554-563.

Glöckner, F., Amann, R., Alfreider, A., Penthaler, J., Psenner, R., Trebesius, K. \& Schleifer, K.-H. 1996. An In Situ Hybridization Protocol for Detection and Identification of Planktonic Bacteria. Systematic and Applied Microbiology 19:403-406 . 
GlöcKner, F.O., Fuchs, B.M. \& AmAnN, R. 1999. Bacterioplankton compositions of lakes and oceans: a first comparison based on fluorescence in situ hybridization. Applied and Environmental Microbiology 65:3721-6.

Glöckner, F.O., Zaichikov, E., Belkova, N., Denissova, L., Pernthaler, J., Pernthaler, A., Amann, R. 2000. Comparative16S rRNA analysis of lake bacterioplankton reveals globally distributed phylogenetic clusters including an abundant group of actinobacteria. Applied and Environmental Microbiology 66:5053-5065.

Grossart, H. P. 1999. Interactions between marine bacteria and axenic diatoms (Cylindrotheca fusiformis, Nitzschia laevis, and Thalassiosira weissflogii) incubated under various conditions in the lab. Aquatic Microbial Ecology 19:1-11.

Jiang, H., Dong, H., Zhang, H., Yu, H., Chapman, L., \& Fields, M. 2006. Microbial diversity in water and sediment of Lake Chaka an athalassohaline lake in northwestern China, Applied and Environmental Microbiology 72:3832-3845.

Karzulovic, J. \& Garda, F. 1979. Evaluación recursos hídricos Provincia de Iquique I Región. Ministerio de Obras Públicas, Dirección General de Aguas; Intendencia I Región; Servicio de Planificación y Coordinación Iquique. Santiago. 205 pp.+ mapas.

Kirchman, D.L. 2002. The ecology of Cytophaga-flavobacteria in aquatic environments. Microbial Ecology 39:91-100.

Kirchman, D.L., Cottrell, M.T., Lovejoy, C. 2010. The structure of bacterial communities in the western Arctic Ocean as revealed by pyrosequencing of $16 \mathrm{~S}$ rRNA genes. Environmental Microbiology 12:1132-1143.

Llobet-Brossa, E., Roselló-Mora, R. \& Amann. R. 1998. Microbial Community Composition of Wadden Sea Sediments as Revealed by Fluorescence In Situ Hybridization. Applied and Enviromental Microbiology 64:2691-2696.

Manz, W., Amann, R., Ludwig, W., Wagner, M. \& Schleifer, K.H. 1992. Phylogenetic oligodeoxynucleotide probes for the major subclasses of Proteobacteria: problems and solutions. Systematic and Applied Microbiology 15:593600 .

Maturrano, L., Santos, F., Rosselló-Mora, R. \& Antón, J. 2006. Microbial Diversity in Maras Salterns, a Hypersaline Environment in the Peruvian Andes. Applied and Enviromental Microbiology 72:3887-3895.

Morin, P.J. \& McGrady-Steed, J. 2004. Biodiversity and ecosystem functioning in aquatic microbial systems: a new analysis of temporal variation and species richness-predictability relations. Oikos 104:458-466.

Muyzer, G., WaAl, E.C. \& Guitterlinden, A. 1993. Profiling of complex microbial populations by denaturing gradient gel electrophoresis analysis of polymerase chain reactionamplified genes coding for $16 \mathrm{~S}$ rRNA. Applied and Enviromental Microbiology 59:695-700.

Nold, S.C. \& ZwarT, G.1998. Patterns and governing forces in aquatic microbial communities. Aquatic Ecology 32:17-35.

Ollivier, B., Caumette, P., Garcia, J. \& Mah, R. 1994. Anaerobic
Bacteria from Hypersaline Environments. Microbiological Reviews 58:27-38.

Oren, A. 2002. Molecular ecology of extremely halophilic Archaea and Bacteria. FEMS Microbiology Ecology 39:1-7.

Pernthaler, J., GlØckner, F., Schönhuber, W. \& Amann, R. 2001. Fluorescence in situ Hybridization (FISH) whith rRNA-targeted oligonucleotide probes. In: Methods in Microbiology: Marine Microbiology (Ed. Paul, J.H. ), pp. 207-226. St. Petersburg, Florida, USA: Elsevier.

Pernthaler, J. \& Amann, R. 2005. Fate of Heterotrophic Microbes in Pelagic Habitats: Focus on Populations. Microbiology and Molecular Biology Reviews 69:440-461.

Rodríguez-VALERA, F. 1988. Characteristics and microbial ecology of hypersaline environments. In: Halophilic Bacteria (Ed. Rodríguez-Valera, F.), pp. 3-30. CRC ress, Boca-Raton, Fla.

Ramette, A. 2007. Multivariate analysis in microbial ecology. Microbial Ecology 62:142-160.

Risacher, F., Alonso, H. \& Salazar, C. 2003. The origin of brines and salts in Chilean salars: a hydrochemical review. EarthScience Reviews 63:249-293.

Seaby, R., Henderson, P., 2007. Community Analysis Package 4.0: searching for structure in community data. PISCES Conservation Ltd. Retrieved 09/01/2012 RLU: http:// www.pisces-conservation.com/index.html? softcap. html\$softwaremenu.html.

Snaird, J., Amann, R., Huber, I., Ludwig, W. \& Schleifer, K. 1997. Phylogenetic Analysis and in Situ Identification of Bacteria in Activated Sludge. Applied and Enviromental Microbiology 63:2884-2896.

Sørensen, K.B., Canfield, D.E. \& Oren, A. 2004. Salinity Responses of Benthic Microbial Communities in a Sola Saltern (Eilat, Israel) Applied and Environmental Microbiology 70:1608-1616.

Stahl, D. A., \& Amann, R. 1991. Development and application of nucleicacid probes. In: Nucleic acid techniques in bacterial systematics (Stackebrandt, E.\& Goodfellow, M.), p. 205-248. John Wiley \& Sons Ltd., Chichester, United Kingdom.

Thiel, V., Tank, M., Neulinger, S. C., Gehrmann, L., Dorador, C. \& IMHofF, J. F. 2010. Unique communities of anoxygenic phototrophic bacteria in saline lakes of Salar de Atacama (Chile). Evidence for a new phylogenetic lineage of phototrophic Gammaproteobacteria from pufLM gene analyses. FEMS Microbiology Ecology 74:510-522.

Ventosa, A. 2006. Unusual microorganisms from inusual habitats: hypersaline environments. In: Prokariotic diversitymechanisms and significance (Eds. Logan, N.A., LappinScott, H.M. \& Oyston, P.C.F.), pp. 223-253. Cambrige University Press, Cambrige.

Wu, Q. L., Zwart, G., Schauer, M. \& M. Hahn, M. 2006. Bacterioplankton community composition along a salinity gradient of sixteen high-mountain lakes located on the Tibetan Plateau, China. Applied and Environmental Microbiology 72: 5478-5485.

Recibido: 19.04.16

Aceptado: 03.11.16 